\title{
Assessment of Occupational Satisfaction on Performance among Employees of a Forest Resources Management Institution in Nigeria
}

\section{${ }^{* 1}$ OMOGHIE, ES; ${ }^{2} \mathrm{BANJO}, \mathrm{AA} ;{ }^{1} \mathrm{ADELEYE}, \mathrm{AS} ;{ }^{3} \mathrm{ALIBOH}, \mathrm{UF} ;{ }^{3}$ SIMPSON, VB}

\author{
${ }^{1}$ Federal College of Forest Resources Management, Sakponba Benin City, Nigeria \\ ${ }^{2}$ Forestry Research Institute of Nigeria, Jericho Hill, Ibadan, Nigeria \\ ${ }^{3}$ Moist Forest Research Station, Forestry Research Institute of Nigeria, Benin City, Nigeria \\ *Corresponding Author Email: eomoghie@gmail.com
}

\begin{abstract}
An organization usually sees an average worker as the source of quality and productivity gains. The study examined the impact of occupational satisfaction on performance among employees of a Forest Resources Management institution in Nigeria using a structured questionnaire for data collection. The data analysis from the study revealed that employee's level of education enhanced job satisfaction. Furthermore, chi-square results showed that there was no significant relationship ( $p>0.05$ ) between personal characteristics and their satisfaction level. In addition, correlation results showed that there was a significant relationship between job satisfaction and employee performance. Thus, the study recommends that organizations should intensify efforts in the area of non-financial rewards as a means of influencing greater performance from the employees as well as getting more employee commitment to the organization.
\end{abstract}

\section{DOI:https://dx.doi.org/10.4314/jasem.v25i2.11}

Copyright: Copyright (C) 2021 Omoghie et al. This is an open access article distributed under the Creative Commons Attribution License (CCL), which permits unrestricted use, distribution, and reproduction in any medium, provided the original work is properly cited.

Dates: Received: 12 December 2020; Revised: 26 January 2021; Accepted: 12 February 2021

Keywords: Assessment, Employee Performance, Occupational Satisfaction, Organization.

Job satisfaction of employees plays a very vital role on the performance of an organization. It is essential to know as to how employees can be retained through making them satisfied and motivated to achieve extraordinary results. Target and achievement depend on employee satisfaction and in turn contribute for organizational success and growth, enhances the productivity, and increases the quality of work. Employee job performance has always been a major challenge in organizational management and adopting effective ways to motivate employees to achieve and deliver higher job performance as well as increase the organizational competitiveness is the main objective of every business organization Lee and $\mathrm{Wu}$ (2011). It is a general understanding that job satisfaction is an attitude towards job, in other words job satisfaction is an affective or emotional response toward various facets of one's job. A person with a high level of job satisfaction holds positive attitudes towards his or her job, while a person who is dissatisfied with his or her job holds negative attitudes about the job. Ogbulafor, 2011; suggested that the deteriorating level in employee performance in Nigerian tertiary institutions is fast becoming a serious threat to survival of universities in Nigeria, which needs to be addressed urgently. It is therefore believed that employee performance is instrumental to organizational growth and profitability. The employees are regarded as the major business resources that facilitate the daily activities and operations of an organization (Mudah, et al., 2014). Similarly, Oluwafemi, 2010; asserted that organizational effectiveness and efficiency depends on how effective and efficient the employees in the organization are. Employee job satisfaction has been interconnected with how people think, perceive, experience and observe their jobs (Spectre, 1997). Robbins and Coulter 2010, defined job satisfaction as the general behavior of employees' attitudes towards their job. The factors that may affect or influence employee's job satisfaction are among others, employee's immediate supervisor, employee's personal characteristics, employee personal practices, employee pay package, working conditions, job security factors etc. Thomas, 2009 opined that when employees have high levels of psychological wellbeing and job satisfaction, they perform better and are less likely to leave their jobs. Howard, 2009 views job satisfaction as a blend of likable and unlikable moods or behavior of an individual worker on their work schedule, implying that when an individual is employed such individual might come along with desires, wants and anticipations, which define their 
meaning for being there. Satisfaction on a job symbolizes the enormousness to which optimism are aligned with real rewards and benefits. Where there is employee job satisfaction, the tendency is to have high turnover, employee commitment and loyalty. Lai Wan, 2007 opines that employee satisfaction is an essential target for any organization to realize or achieve in short run or long run. Low level of employee satisfaction generates low employee turnover and the turnover intention is the desire to leave an organization (Saghir et al., 2015). According to Mowday et al., 2013, most employees of today have a high degree of job dissatisfaction, which creates attitudes that are undesirable on the job and in turn degenerate their performance ability and their working place as well. Rue and Byar, 2003 suggests that job satisfaction is determined by some elements in the workplace, which include financial packages like salaries, opportunities, advancement, working conditions, and work group. The resultant effect of the determinant serves as yardstick for job satisfaction or dissatisfaction as well as what the outcome will be, asserted by Aziri, 2011that when discussing issues regarding job satisfaction, job dissatisfaction should be considered in order to ensure balance. However, research on job satisfaction among employees are scarce, therefore this paper evaluates the occupational satisfaction on performance amongst employees of Forest Resources Management institution in Nigeria.

\section{MATERIALS AND METHODS}

Sample Collection and Analysis:This research made use of the survey research design to allow the researcher make more reliable conclusions on job satisfaction and its impact on employees'performance.

The survey research design adopted became imperative because of the population characteristics and a representative nature of the sample of the population for the study. The population for the study involved all the employees both academic and nonacademic staffs of the Federal College of Forest Resources Management, Sakponba, Benin City, Edo State.

The population for the study was 129 as at the time of data collection. The sample size was ninety-five (95) as respondents were randomly selected from the population studied. The sample size was large enough and served as an adequate representation of the population.

Hypotheses of the Study: $H^{o l}$ : There is no significant relationship between employee personal characteristics factors and employee job satisfaction.
$\mathbf{H}^{\mathbf{0} 2}$ : There is no significant relationship between employee job satisfaction and employee performance.

\section{RESULTS AND DISCUSSION}

Results from Table 1 revealed from the study that $28.4 \%$ were within 30 to 39 years of age, $(40 \%)$ were within 40 to 49 years of age, and $9.5 \%$ were 50 years and above. This implies that the respondents were matured enough to participate in this study. Also, $13.7 \%$ had SSCE, $24.3 \%$ were ND/NCE holders, $41.1 \%$ were B.Sc/HND holders, and $21.0 \%$ had Masters Degrees.

This implied that they were knowledgeable enough to respond to questions contained in the questionnaire. Furthermore, $9.5 \%$ of the respondents had spent less than 2 years on the job, $21.1 \%$ had spent between 2-5 years on the job, $25.3 \%$ had spent between $6-10$ years, $33.7 \%$ had spent between $11-15$ years in the institute while $10.5 \%$ had spent over 15 years in the institute. This implies that they had proper knowledge about their workplace. They were therefore in a position to give information on how job satisfaction had affected their performance.

Table 1: Personal characteristics of the respondents

\begin{tabular}{lll}
\hline Age & Frequency & Percentage (\%) \\
\hline Less than 20 years & 5 & 5.3 \\
20-29 years & 16 & 16.8 \\
30-39 years & 27 & 28.4 \\
$40-49$ years & 38 & 40 \\
Above 50 years & 9 & 9.5 \\
Educational Qualification & & \\
S.S.C.E & 13 & 13.7 \\
ND/NCE & 23 & 24.3 \\
DEGREE/HND & 39 & 41.1 \\
MASTERS & 20 & 21.0 \\
PhD & 0 & 0 \\
Working Experience & & \\
Less than 2 years & 9 & 9.5 \\
2-5 years & 20 & 21.1 \\
6-10 years & 24 & 25.3 \\
11 -15 years & 32 & 33.7 \\
Above 15 years & 10 & 10.5 \\
\hline & Source: Field survey, 2020.
\end{tabular}

Table 2: Results on the relationship between job satisfaction and employee performance among employees in the organization.

\begin{tabular}{lll}
\hline Statements & YES & NO \\
\cline { 2 - 3 } & $\begin{array}{l}\text { Frequency } \\
(\%)\end{array}$ & $\begin{array}{l}\text { Frequency } \\
(\%)\end{array}$ \\
\hline $\begin{array}{l}\text { Does your organization promote } \\
\text { staffs as at when due? }\end{array}$ & $67(70.50$ & $28(29.5)$ \\
$\begin{array}{l}\text { Does the nature of employee's } \\
\text { job commensurate with your pay? }\end{array}$ & $50(52.6)$ & $45(47.4)$ \\
\hline $\begin{array}{l}\text { Source: Field survey, 2020 } \\
\text { * }\end{array}$ & parenthesis indicates percentage
\end{tabular}

Table 2revealed that majority $70.5 \%$ said the organization promotes staffs when due and $47.4 \%$ said the nature of job does not commensurate with their pay 
Table 3: Results on factors that influence job satisfaction and improve satisfaction level of employees

\begin{tabular}{|c|c|c|c|c|c|}
\hline \multirow[t]{2}{*}{ Statements } & $\begin{array}{l}\text { Strongly } \\
\text { Agree }\end{array}$ & Agree & Neutral & Disagree & $\begin{array}{l}\text { Strongly } \\
\text { Disagree }\end{array}$ \\
\hline & Freq $(\%)$ & Freq $(\%)$ & Freq $(\%)$ & Freq $(\%)$ & Freq $(\%)$ \\
\hline $\begin{array}{l}\text { Employees are Satisfied } \\
\text { with the working } \\
\text { conditions of the } \\
\text { Organization }\end{array}$ & $23(24.2)$ & $29(30.5)$ & $24(25.3)$ & $13(13.7)$ & $6(6.3)$ \\
\hline $\begin{array}{l}\text { Years of experience } \\
\text { influences job satisfaction }\end{array}$ & 17 (17.9) & 27 28.4) & $21(22.1)$ & $19(20.0)$ & 11 (11.6) \\
\hline $\begin{array}{l}\text { Employees' level of } \\
\text { education enhances job } \\
\text { satisfaction }\end{array}$ & $60(63.1)$ & 11 (11.6) & $5(5.3)$ & $7(7.4)$ & $12(12.6)$ \\
\hline $\begin{array}{l}\text { Employee empowerment } \\
\text { promotes job satisfaction }\end{array}$ & $20(21.1)$ & 31 (32.6) & 30 (31.6) & $9(9.5)$ & $5(5.3)$ \\
\hline $\begin{array}{l}\text { Supervisors attitudes } \\
\text { impacts on Job }\end{array}$ & 13 (13.7) & $26(27.4)$ & $29(30.5)$ & $11(11.6)$ & $16(16.8)$ \\
\hline Satisfaction & & & & & \\
\hline $\begin{array}{l}\text { The Organization shows } \\
\text { concern about staff welfare }\end{array}$ & $19(20.0)$ & $41(43.2)$ & $10(10.6)$ & $19(20.0)$ & $6(6.2)$ \\
\hline $\begin{array}{l}\text { Employees are willing to } \\
\text { work at the organization } \\
\text { till retirement }\end{array}$ & 11 (11.6) & 27 (28.4) & $33(34.8)$ & 12 (12.6) & $12(12.6)$ \\
\hline
\end{tabular}

Results from table 3 revealed that $6.3 \%$ strongly disagreed and $24.2 \%$ strongly agreed that employees are satisfied with the working conditions of the organization. Majority $63.1 \%$ strongly agreed that employees' level of education enhances job satisfaction however only a few $5.3 \%$ strongly disagree that employee empowerment promotes job satisfaction. This implies that education helps at improving workers willingness to work. This supports the assertion by Hall, 1994 that there is a positive relationship between education and job satisfaction. Furthermore, $16.8 \%$ strongly disagreed that supervisor's attitude impacts on job satisfaction while $11.6 \%$ disagreed whereas $13.6 \%$ strongly agreed. Results further showed that $6.2 \%$ strongly disagreed, $20.0 \%$ disagreed, $43.2 \%$ agreed and $20.0 \%$ strongly agreed that the organization shows concern about staff welfare. Among the employees sampled, only $11.6 \%$ strongly agreed that employees are willing to work with the organization till retirement. This implies that employees will work in an organization for a long time if well motivated.

Test of Hypotheses: $\mathrm{H}^{\mathrm{o}}$ : The result of the Chi-square analysis in Table 4 shows that there was significant relationship $(p<0.05)$ between sex $\left(\chi^{2}=4.037\right)$ and the factors improving satisfaction level in an organization. While there is no significant relationship ( $\mathrm{p}>0.05)$ between age $\left(\chi^{2}=2.975\right)$, marital status $\left(\chi^{2}=2.195\right)$, staff $\left(\chi^{2}=1.080\right)$, educational level $\left(\chi^{2}=5.107\right)$, length of service $\left(\chi^{2}=3.281\right)$ and the factors improving satisfaction level in an organization. The result of the analysis revealed that sex has effect on the factors improving job satisfaction level in an organization while, age, marital status, staff, educational level and length of service have no relationship with the factors improving job satisfaction. This is supported by Olorunsola, 2012 that personal characteristics such as age and sex do not influence job satisfaction.

Table4: Chi-square result on relationship between the personal characteristics of the respondents and the factors improving job satisfaction in the organization.

\begin{tabular}{lllll}
\hline Variables & $\boldsymbol{\chi}^{2}$-value & Df & p-value & Decision \\
\hline Age & 2.975 & 4 & 0.562 & NS \\
Sex & 4.037 & 1 & 0.045 & S \\
Marital status & 2.195 & 2 & 0.334 & NS \\
Staff & 1.080 & 1 & 0.299 & NS \\
Educational level & 5.107 & 4 & 0.227 & NS \\
Length of service & 3.281 & 4 & 0.512 & NS \\
\hline
\end{tabular}

$\mathrm{H}^{\mathrm{o} 2}$ : The result of correlation in Table4 shows that there is significant relationship $(p<0.05)$ between the job satisfaction $(r=0.266)$ and employee performance in an organization. This shows that job satisfaction determines the employee performance in an organization.

Table 5: Correlation result on relationship between the job performance and employee performance in the study area

\begin{tabular}{llll}
\hline Variables & R-value & p-value & Decision \\
\hline $\begin{array}{l}\text { Job performance vs } \\
\text { Employee performance }\end{array}$ & 0.266 & 0.009 & $\mathrm{~S}$ \\
\hline
\end{tabular}

Conclusion: The study showed that employees' personal characteristics and wages influenced occupational satisfaction. It was discovered that work experience facilitated job satisfaction. Majority of the staffs agreed that the organization showed concern about her employees, which further showed their willingness to work at the organization until retirement. Organizations should pay more attention to salaries paid, bonuses, arrears, incentives and 
employee empowerment to promote employee job satisfaction in order to enhance their performance.

\section{REFERENCES}

Aziri, B (2011). Job Satisfaction: A Literature Review. Manage. Res. Pract. 3(4): 77-86.

Hall, R (1994). Sociology of Work: Perspectives, Analysis and Issues. Pine Forge Press pp. 465

Howard, AD (2009). An Exploratory Examination of Positive and Negative Emotional Attractors Impact on Coaching International Change. Doctoral Dissertation, Case Western Reserve University.

Lai Wan, H (2007). Human Capital Development Policies: Enhancing Employees' Satisfaction. J. Eur. Indus Train, 31(4): 297 - 322.

Lee, YR; Wu, MY (2011). The Effect of Internal Marketing, Job Satisfaction and Service Attitude on Job Performance among High-tech Firm. Afr. J. Bus. Mgt. ISSN 1993-8283

Mowday, RT; Porter, LW; Steers, RM (2013). Employee - Organization Linkages: The Psychology of Commitment, Absenteeism and Turnover. Academic Press.

Mudah, I; Rafiki, A; Harahap, MR (2014). Factors Influencing Employees' Performance: A Study on the Islamic Banks in Indonesia. Int. J. Bus Soc. Sci. 5(2).

Ogbulafor, C (2011). Motivation and Job Performance of Academic Staff of State Universities in
Nigeria: The Case of Ibrahim Babangida University, Lapai, Niger State. Int. J. Bus. Mgt. 7(14): 142

Olorunsola, EO (2012). Job satisfaction and Personal Characteristics of Administrative staff in South West Nigeria Universities. J. Emerging Trends in Edu Res and Polstud. (JETERAPS) 3(1):46 -50.

Oluwafemi, OJ (2010). Contextual Dispositional Factors, Turnover Intention and Perceived Job Alternatives as Predictors of Organizational Citizenship of Behaviour of Employees of Nigeria Oil Industry University of Ibadan, An unpublished $\mathrm{PhD}$ Thesis

Robbins, S.P; Coulter, M (2010). Management, $10^{\text {th }}$ Edition, UK: Pearson.

Rue, L; Byar, L (2003). Management: Skills and Application. McGraw-Hill Higher Education

Saghir, A; Asad, U; Ishtiaq, A (2015). Relationship between Employee Job Satisfaction and Turnover Intention in Microfinance Banks in Pakistan. Res. J. Com, Econ, and Soc. Sci. 9 (1):123 - 137.

Specter, P (1997). Job Satisfaction: Application, Assessment, Causes and Consequences, Thousand Oaks, CA, Inc (Vol. 3). Sage Publications.

Thomas, C (2009). The Interaction of Job Satisfaction, Job Search and Job Changes. An Empirical Investigation with German Panel Data. J. Hap. Stud. 10(3):367 - 384. 